\title{
A community of advantage or mutual respect?
}

\author{
Shaun P. Hargreaves Heap ${ }^{1}$
}

Received: 22 May 2020 / Accepted: 27 May 2020 / Published online: 28 July 2020

(c) The Author(s) 2020

\begin{abstract}
This paper reviews the points of continuity and change between Sugden's new book and his classic from the 1980s, The Political Economy of Welfare, Rights and Cooperation. It argues that while his new responses to the 'nudging' revolution and rising inequality have sharpened his argument for, respectively, the economist as 'contractarian' adviser to citizenry model and his defence of the market as an institution of mutual benefit, the introduction of Adam Smith's concept of 'mutual sympathy' is double-edged. It fills a psychological gap in Hume that is important for "contractarian' proposals to citizenry, but it also suggests we might plausibly be interested in something more than mutual benefit when deciding what rules to be regulated by.
\end{abstract}

Keywords Mutual advantage $\cdot$ Mutual respect $\cdot$ Contractarian $\cdot$ Fairness

JEL Classification D6 - D7 · D8

\section{Introduction}

Bob Sugden has returned, magisterially in his new book to the themes of his seminal work of the 1980s, The Political Economy of Welfare, Rights and Cooperation (Sugden 1986). In this paper, I shall reflect on the key points of continuity and change and where that leaves his argument commending the market to us, as citizens, as what we should agree among ourselves to regulate our lives.

One way of appreciating what has and has not changed with the new volume is to name check the enduring influence of some of the 'greats' in economics across the two books, and note the arrival of new ones in The Community of Advantage: A Behavioural Economist's Defence of the Market. The enduring influences are Buchanan, Hayek and Hume. They provide two things in both books: a distinctive defence of the market and a distinctive, 'contractarian-based', approach to what economists should be doing when offering 'policy advice'.

Shaun P. Hargreaves Heap

shaun.hargreaves_heap@kcl.ac.uk

1 King's College London, London, UK 
The new arrivals are Mill and Smith. Although the title of the book is a nod to Mill, I shall argue that Smith is the key, and a troubling, new addition. He arrives to plug a gap in Hume's argument for relying on mutual advantage but, I suggest, he brings some uncomfortable baggage for a central argument in The Community of Advantage: A Behavioural Economist's Defence of the Market. The idea of 'mutual sympathy' plugs a psychological gap in Hume over why individuals who care about own advantage should follow rules that, while mutually beneficial, do not always maximize own advantage. 'Mutual sympathy' does this. However, it is also potentially double-edged in its effect on the argument. It may, as Sugden argues, cement psychologically individual commitment to institutions of mutual advantage, but I shall argue in Sect. 3 that it also introduces another consideration into the evaluation of institutions: mutual respect. This need not blunt the argument for the market as an institution of mutual advantage so long as markets do not undermine the scope for mutual respect. The trouble is, I shall argue in Sect. 4, they might.

Before I develop the idea that introducing Smith may be double-edged in more detail, I shall discuss in the next section two other modifications to his argument for a society of mutual advantage. They arise from two important developments since he wrote The Political Economy of Welfare, Rights and Cooperation. One comes from inside the academy: the rise of behavioural economics and 'nudging' as a kind of policy intervention. The other is the increase in inequality in most rich countries. His response to both significantly sharpens both his defence of the market and his model of the economist as policy adviser, that is, someone who needs a loudspeaker to address fellow citizens rather than a comfy chair to sit in while whispering in the ears of would-be social planners.

In the last section, I conclude by bringing Hayek back into the argument as a source of scepticism over whether we will sign up, 'contractarian' style, for institutions of mutual benefit. Put simply, he points to why we might well want more from our institutions. Indeed, what more we want has an obvious connection to the earlier argument on the double-edged nature of Smith's 'mutual sympathy' and so reinforces this point.

\section{The rise of behavioural economics and inequality}

In both books, Sugden argues against a common view where the State is some kind of social planner deciding what to do in the public interest, aided by an economist, cast as whisperer-in-chief, conveniently seated by the ear of the planner. This is the first key Sugden argument, and, instead, he locates economic advice in a 'contractarian' tradition. The State exists in this tradition through our (implicit) agreement as citizens to be regulated in this way, and so its character should satisfy a unanimity requirement among the citizenry. This is Buchanan, especially, and sometimes Hayek on how to think about the State. Thus, what economists can do is make recommendations to fellow citizens over the character of the institutions/rules they might plausibly all agree to be regulated by. In other words, what the economist needs is a 'loudspeaker' to address fellow citizens and not that comfy chair, next to the social planner, for easy 'whispering'. 
What might the recommended institutions be? They would be institutions that secured mutual benefit because, in this way, all will have reason to agree to them. Of course, many institutions might satisfy this requirement and some might give more benefit to some than others. This might be a reason for preferring one such arrangement to another but not for rejecting them entirely. I shall return to this point later because one way of introducing how mutual respect might get into the argument is that the variety of institutions of mutual advantage may differ in the scope they offer for mutual respect and this is something that may also interest the citizenry. But this is to get a little ahead of what I want to say later.

The second key Sugden argument is that the market is an institution of mutual advantage and so should commend itself to citizens. This argument draws on Hayek rather than Arrow-Debreu when explaining how well markets function. It is also importantly supplemented, in what is a pincer movement to keep the State in its place, by Hume on how conventions around trust and reciprocation that help secure mutual advantage in markets can spring up spontaneously. They will do much of the job to prevent the kind of market failure that is the usual cause for government regulation. This was the exciting terrain that Sugden opened up in The Political Economy of Welfare, Rights and Cooperation with his application and development of evolutionary game theory and its place in his overall argument is much like that of Hayek in his mature work.

Two things have happened since the elements of this argument were assembled in The Political Economy of Welfare, Rights and Cooperation and which help explain much of the changes in the new volume. The first is most easily explained. There has been a growth in income inequality in most rich countries over the last 30-50 years, and it is such that for some people, at least, it is possible that the operation of markets has made them worse off over this period or over significant parts of this time period. In other words, there must be some doubt that markets would receive the unanimous endorsement by the citizenry that 'contractarians' seek because they have not proved to be self-evidently institutions that promote everyone's benefit in recent times.

There is no mystery to this in the sense that markets are institutions that secure mutual benefit by definition only for those who are parties to the exchange. There is always scope for third-party spillover effects that may be negative. It has always been an empirical question as to whether the distribution of any negative spillover effects might be such that some in the population might actually lose out on balance, even after taking account of the exchanges that they engage in and that do secure benefits. It just so happens that the combination of globalization, technological change and whatever has been responsible most recently for the surge in top salaries has plausibly produced such an eventuality and there has been no spontaneous generation of compensatory institutions. As a result, Sugden now modifies the recommendation that goes to fellow citizens: the institution of the market is buttressed by State guarantees to ensure that any such negative spillovers cannot dominate the gains from trade for any person.

This is a welcome change, not unlike Hayek's similar support for something like a Universal Basic Income in the later chapters of The Constitution of Liberty, and I 
think it moves Sugden much closer to Mill and so firms up this new influence. It also makes his argument for a market society much more persuasive.

The second change is the rise of behavioural economics, and this takes much more space to deal with in the new volume. Sugden could rightly feel that history has been more than a little unkind in this matter. He is, after all, one of the pioneers of behavioural economics, and an impartial observer might imagine that, as one of its central messages is that we often do not have preference orderings over outcomes to guide our decisions, this would play powerfully into Sugden's broader argument about markets and role of the economist as an adviser to citizens contemplating what to agree to. This is because Sugden like Hayek crucially (and unlike the conventional argument for markets in the analysis of Arrow-Debreu) makes markets a virtue precisely in circumstances where we do not have well-defined preferences and preference orderings to guide behaviour. But, no: this is not what happened. In some strange twist of history, behavioural economics popularly became a source for new kinds of State intervention, 'nudging', and to add insult to injury, 'nudging' injects life into the model of the economist as whisperer in the ear of the social planner. New 'whisperers' have popped up all over the place, just as you might have thought there would have been a run on 'loudspeakers'.

History cannot be re-wound to make things right—even Doctor Who does not do this. But the errors of 'nudging' can be set straight, and this is what Sugden does to good effect in much of the first part of the new volume. I think he is right both to do and in the arguments he makes. Nevertheless, I am left to wonder how it happened. How can history have been so unkind? How can a liberal society have been persuaded to engage in new forms of paternalism on the grounds that when people do not behave as if they had a preference ordering, it is not because they do not have such a thing, it is because they have inadvertently failed to follow it. Surely, the simpler explanation is that when people do not act as if they had a preference ordering....errr, they do not have one! Whatever happened to Ockam's razor?

\section{The legacy of Hume}

Hume (1738) wonderfully explains how following rules of trust and reciprocation can yield mutual benefit and Sugden has previously shown formally what Hume had, in effect, suggested: some of these rules might evolve in an evolutionary setting without any need for State intervention. The difficulty with this explanation is that the people who need to follow these rules in practice are not the backward looking agents assumed in evolutionary models (i.e. simple rule followers where the probability of the rule being used depends on its success in the past). People in the real world are alert to their own advantage and must find following the rule rather than breaking it to their advantage, and we know that this will not always be the case. So what bridges this fault line between an individual psychology of seeking own advantage and the following of rules of trust and reciprocation that, while mutually beneficial, may not always strictly maximize own advantage?

The question assumes more importance in The Community of Advantage: A Behavioural Economist's Defence of the Market because its 'contractarian 
'character is more evident. What an economist proposes to fellow citizens has to be credible. It has to satisfy a requirement of reflective equilibrium, which, in this case, means that the recommendation is consistent with what we know about human psychology. In The Political Economy of Welfare, Rights and Cooperation, Sugden plugged the motivational gap by developing an argument that seems to be in Hume regarding how people do not like to disappoint other people's expectations. This has the effect of insulating a set of rules of trust and reciprocation, once established, from being breached by anyone who might find this in their material self-interest because they would suffer a negative psychological charge from disappointing others' expectations.

The difficulty with this Humean argument is twofold. First, it's not self-evident that we are psychology pre-disposed to avoid disappointing others' expectations. Of course, we are sometimes but far from always. It seems to depend how valid we judge such expectations to be before we give them influence over our actions. Second, the argument depends on the rules having been established and seems therefore to beg the question that actually needs answering: namely, would people credibly sign up to and follow the rules, ab initio?

Smith potentially answers the first of these problems with the concept of 'mutual sympathy' and therefore also avoids the second: that is, we enjoy a special pleasure from knowingly experiencing the same sympathy as others. For Sugden, this means that we have reason to follow rules of mutual advantage because when we so do, we know that we will be experiencing individual advantage in the same way that others are. To transgress a rule of mutual advantage would be to undermine the experience of this special pleasure, and that is why we do not.

Sugden's solution elegantly does the trick, but I am not persuaded that this is what Smith had in mind and, indeed, that it is really that psychologically plausible, whereas what Smith did have in mind is psychologically plausible. Smith argues that 'mutual sympathy' comes from a concordance in individual judgments about the worth of an experience/action. It is a shared evaluation of the action, and this matters because people are concerned with their self-worth or self-respect. This is why Smith often finds that these judgments are the basis for approval/disapproval of actions. The evaluative dimension is also crucial in Smith's explanation why the judgments have to be shared: it is because individual qua individual judgment would be prone to be self-serving. That is, if one's judgment of self-worth was purely personal, it could not, in the presence of a temptation to be self-serving, escape from being in some degree suspect and so prove a weak foundation on which to base an evaluation of worth. We rely instead on the rules of conduct revealed in other people's behaviour. Here is a key passage from Smith's Theory of Moral Sentiments where these points are made.

The opinion which we entertain of our own character depends entirely on our judgments concerning our past conduct. It is so disagreeable to think ill of ourselves, that we often purposely turn away our view from those circumstances which might render that judgment unfavourable. He is a bold surgeon, they say, whose hand does not tremble when he performs an operation upon his own person... So partial are the views of mankind with regard to 
the propriety of their own conduct... Nature, however, has not left this weakness, which is of so much importance, altogether without a remedy; nor has she abandoned us entirely to the delusions of self-love. Our continual observations upon the conduct of others, insensibly lead us to form to ourselves certain general rules concerning what is fit and proper either to be done or to be avoided (Smith 1759, Part III, ch iv)

Smith's account is more plausible in two respects. It grounds 'mutuality' in an epistemic problem concerning the worth of an action, and it allows that our judgments about the worth of an action might involve many considerations in addition to whether the action is consistent with the rules of mutual benefit. For example, one might consider the worth of an action by how fair, honourable, etc., and, perhaps, even how beautiful it was. In other words, we may need rules for justice, honour and aesthetics and not just mutual advantage when mutual respect consists of more than mutual advantage.

\section{A tension between mutual respect and mutual advantage?}

Sugden can concede that 'mutual sympathy' depends on more than shared judgment that actions follow the rules of mutual advantage without undermining his argument that the rules of the market, trust and reciprocation are what economists can recommend to citizens in several ways.

First, he could argue that the institutions that orchestrate shared judgments on aesthetics, fairness, etc., and other potential components of 'mutual sympathy' are built on institutions of mutual advantage. So, in other words, follow the prescription for mutual advantage and you get the rest.

Second, he could argue that the domains of the market and mutual advantage are importantly separate from the domains where other kinds of value are manufactured. So, following the prescription for mutual advantage is narrowly what an economist has to contribute to the 'contractarian' debate over how to regulate a society and it can be separated from other non-economic considerations.

Thirdly and perhaps more boldly, as a different and stricter version of the first, he might argue that talk of honour, fairness and beauty can really be collapsed into his rules for trust and reciprocation. So although worth depends on more than mutual advantage, it consists of judgments about the value of trust and reciprocation alone and they can be grounded in the rules of mutual advantage.

Casual empiricism makes the last of these possible rejoinders look weak as we seem to place value and make value judgments that stretch beyond trust and reciprocation. The first has some plausibility (e.g. see Cowen 1998) but has difficulty accounting for the variety of norms of fairness, for instance, that have arisen in market societies (e.g. see Hall and Soskice 2001). So the invitation to consider the rules of mutual benefit does not by itself also select from among the other norms that we use while being in market society. This echoes my earlier observation, and it is also the case for the second argument. If this was the only problem, then the argument for rules of mutual benefit becomes 'modest' in the sense that it is simply a contribution 
to what is larger 'contractarian' enterprise, with other non-economist potential contributors. Modesty may not excite, but there is nothing wrong with it.

The difficulty, however, with this modest casting of the argument comes from the evidence on 'crowding out' in economics. This suggests that markets and market incentives, by appealing or making more salient the individual (often material) incentives to action can, in some circumstances 'crowd out' other pro-social sources of motivation in an interaction/exchange (e.g. see Frey 1997; Falk and Szech 2013). Of course, there are examples of 'crowding in' (see the meta-study by Bowles and Polania Reyes (2012), but 'crowding out' examples dominate), and I suspect that the evidence often overlooks that markets boost equal treatment types of procedural fairness (see Hargreaves Heap et al. 2013). Nevertheless, there are deeper reasons for supposing that there is some antagonism between the norms of mutual benefit and those of mutual respect.

One such reason is that norms of mutual benefit thrive on individual difference, while norms of mutual respect require shared views of what matters. There is a tension here between diversity and homogeneity in a population. This is not simply theoretical because the tension has been experienced in many rich countries recently around the issue of immigration and votes like those of BREXIT. This should alert us to the possible difficulty of aligning mutual benefit with mutual respect.

Another reason is that markets are disruptive. It is in the nature of the dynamism we associate with market societies that there is constant motion and this again conflicts with what we also know about norms of mutual respect: they grow roots in settled communities. Indeed, Smith in the Wealth of Nations worried about the growth engendered by markets precisely because it uprooted people from settled rural communities and transplanted them in the bustle, change and anonymity of the city, where he thought they would fall prey to the (false) assurances offered by religious sects.

The reason that 'crowding out' matters is that 'contractarians' when making recommendations to the citizenry have now to weigh what have become, at least to some degree, competing claims regarding whether the rules of mutual benefit or mutual respect should have the upper hand. An elegant and compelling argument for the virtues of agreeing to the rules of mutual benefit is no longer decisive. It must be set against other claims about what makes a society worth living in. I rather hope this is the challenge that Bob Sugden takes up next.

\section{Conclusion}

Sugden has written a compellingly persuasive book for the 'contractarian' approach to thinking about the institutions of society and the role of economic advice. It is particularly powerful in rebutting the new fuel from behavioural economics for the traditional 'whispering in the ear of the social planner' approach. I hope it will help shift normative/welfare economics centrally to a discussion of rules and not outcomes. It needs to. 
It is the other key argument of the book - that the rules of mutual advantage in the form of the rules of markets, trust and reciprocation can be recommended to citizens - that I have doubts about. I have focused on the problematic introduction of Adam Smith's 'mutual sympathy' into this argument. I will conclude with a more practical source of scepticism. It is home-grown, so to speak for Sugden, because it comes from Hayek and seeds doubts over whether the rules of mutual advantage will actually, in practice, secure the 'contractarian' requirement of unanimity.

Hayek (1945) makes the case for markets on informational grounds. It is because there is an informational problem that markets commend themselves. This is the same line that Sugden takes on markets. In this, I am sure he is right, and the less economics warbles about Pareto efficiency, the more useful is it likely to become. But, Hayek (1960) notices a corollary of this. One way of characterizing the information problem is that in a complex society with an advanced division of labour, geographically spread across the world, there are actually lots of things that, in principle, can affect the outcomes associated with an individual's decisions which he or she simply cannot know about, and certainly cannot form expectations about. No one person, let alone most people, can be expected to understand and anticipate probabilistically all that might happen. Another way of saying this is that most people will experience much of what happens in a market economy as driven by 'luck' rather than the 'merit' that comes from individual calculation given reasonable (let alone 'rational') expectations. This is very important. Hayek knows it is a problem, but he thinks, in effect, we just have to 'take this on the chin'. It is just the way it is. The trouble for securing unanimity is: we do not 'take it on the chin'.

We do not, in general, think that outcomes driven by 'luck' are fair and that, in turn, means, in practice, we are persuaded to have a layer of redistributive institutions in society whenever 'luck' plays a significant role in economic outcomes (see Cappelen et al. 2013). This is why I have my doubts that all people will agree to the rules of mutual benefit when the virtues of the market are sold through Hayek's great insight about markets as responses to deep informational problems in complicated societies. Hayek's argument alerts us to luck, and in its presence, we will always want something more than markets. We will want institutions of fairness. Sugden makes a concession in this direction when adjusting his argument to take account of the increasing inequality since the mid-1980s. The point to note, however, is that concession has nothing to do with fairness: it is just to get those who might otherwise lose out under markets to sign up to the project. A concern for 'fairness' is going to need something more.

This, of course, connects directly with Smith on 'mutual sympathy' and its extension to shared values of fairness (and other sources of worth). Quite simply, we expect more from the institutions we sign up to than mutual benefit....and why should not we when there is more to life?

Open Access This article is licensed under a Creative Commons Attribution 4.0 International License, which permits use, sharing, adaptation, distribution and reproduction in any medium or format, as long as you give appropriate credit to the original author(s) and the source, provide a link to the Creative Commons licence, and indicate if changes were made. The images or other third party material in this article are included in the article's Creative Commons licence, unless indicated otherwise in a credit line to the material. If material is not included in the article's Creative Commons licence and your intended use is 
not permitted by statutory regulation or exceeds the permitted use, you will need to obtain permission directly from the copyright holder. To view a copy of this licence, visit http://creativecommons.org/licen ses/by/4.0/.

\section{References}

Bowles S, Polania Reyes S (2012) Economic incentives and social preferences: substitutes or complements. J Econ Lit 50(2):368-425

Cappelen A, Konow J, Sorensen E, Tungodden B (2013) Just Luck: an experimental study of risk taking and fairness. Am Econ Rev 103(4):1398-1413

Cowen T (1998) In praise of commercial culture. Harvard University Press, Cambridge

Falk A, Szech N (2013) Morals and the market. Science 10:707-711

Frey B (1997) A constitution for knaves crowds out civic virtue. Econ J 107(1997):1043-1053

Hall P, Soskice D (2001) Varieties of capitalism. Oxford University Press, Oxford

Hargreaves Heap S, Tan J, Zizzo D (2013) Trust, inequality and the market. Theor Decis 74:311-333

Hayek F (1945) The use of knowledge in society. Am Econ Rev 35(4):519-530

Hayek F (1960) The constitution of liberty. Routledge, London

Hume D (1738) A treatise of human nature. HarperTorch ibook edition

Smith A (1759) The theory of moral sentiments. Strand \& Edinburgh: A. Millar; A. Kincaid \& J. Bell

Sugden R (1986) The economics of rights, co-operation and welfare. Basil Blackwell, Oxford

Publisher's Note Springer Nature remains neutral with regard to jurisdictional claims in published maps and institutional affiliations. 